\title{
Rat Anatomy Concepts
}

National Cancer Institute

\section{Source}

National Cancer Institute. Rat Anatomy Concepts. NCI Thesaurus. Code C60538.

Body tissues, cavities, fluids, organs, or systems pertaining specifically to rat anatomy. 